\title{
Assessment of Investment Projects Based on Economic Flow and Not in Cash Flows
}

\author{
Halil Kukaj ${ }^{1}$ and Fisnik Morina ${ }^{2}$
}

\begin{abstract}
In terms of global competitiveness, taking the investments decisions has a great impact to remain in the market. For this, when evaluating the investing projects it is necessary to apply the methods of profitability and liquidity. However, the question arises, if the profitability evaluation of investing project should be made according to the cash flow or the data from the economical flow statement. The aim of this paper is to give arguments why the economical flow statement should be applied instead of cash flow statement for the evaluation of profitability of investing projects. The paper is based on a hypothetical example whereas arguments are derived while applying the indicators: the Net present value and internal norm of profitability.
\end{abstract}

Keywords: Evaluation of investing project, economical flow, net present value, internal norm of profitability

\section{Introduction}

Recently, economic operators are encountered with global competitiveness. In these conditions, financial management decisions for selecting the investing project for implementation weigh more because only the businesses with a big scale of profitability succeed to remain in the global competitiveness, always fiercer.

This paper aims to argument that modern methods of evaluation of investing project should be based on the economic flow statement and not in the cash flow statement as many other authors think in their papers regarding the same subject.

For the ascertainment of arguments, modern evaluation methods of investing projects are applied, whereas the indicators are calculated regarding the data of economical flow statement and the data of the cash flow statement of a hypothetical investing project.

\section{Evaluation of Investing Project}

Investing decisions are taken according to the liquidity and profitability indicators, which result from the evaluation of investing project. The calculation of these indicators, respectively the evaluation of investing project should be made according to the reliable data gathered on the cash flow statement and on the economical flow statement.

A considerable number of authors in their papers regarding this area of study, consider that the evaluation of investing project should be made according to the reliable data gathered in the cash flow statement. However, only businesses with a great scale of profitability are able to remain this global competitiveness recently.

Thus, we think that the evaluation of liquidity should be made according to the data gathered in the cash flow statement whereas the evaluation of profitability of investing project should be made according to the reliable data gathered on the economical flow

\footnotetext{
| 1 University "Ukshin Hoti” - Prizren, Kosovo

2University "Haxhi Zeka" - Peja, Kosovo, (corresponding author)
} 
statement because the indicators of profitability which result from the data of economical flow are more reliable for the appropriate selection of the investing project from the investing projects program.

\section{The Net Present Value as an Indicator of Profitability}

In order to calculate the Net Present Value according to the cash flow and economical flow, we will be based on hypothetical examples. Below the net present value will be calculated according to the cash flow for the project $\mathrm{A}$ and project $\mathrm{B}$ :

\begin{tabular}{|l|l|c|c|c|c|c|c|}
\hline Project A & \multicolumn{6}{|c|}{ Cash Flow } \\
\hline \multirow{2}{*}{ No. } & Description & \multicolumn{5}{|c|}{ Years } \\
\cline { 2 - 9 } & & 0 & 1 & 2 & 3 & 4 & 5 \\
\hline I. & Receivables & 785.700 & 972.000 & 1.097 .000 & 1.097 .000 & 1.093 .700 & 1.072 .085 \\
\hline $\mathbf{1 .}$ & Revenue from sale & - & 972.000 & 1.097 .000 & 1.097 .000 & 1.093 .700 & 812.000 \\
\hline & Own financial resources & 235.700 & - & - & - & - & - \\
\hline & Loans & 550.000 & - & - & - & - & - \\
\hline & Residual value & - & - & - & - & - & 260.085 \\
\hline II. & Payments & 785.700 & 771.843 & 1.090 .665 & 1.092 .020 & 1.090 .484 & 750.351 \\
\hline $\mathbf{1}$ & Investments & 785.700 & - & - & - & - & - \\
\hline $\mathbf{2}$ & $\begin{array}{l}\text { Expenditures }(\text { excluding } \\
\text { depreciation })\end{array}$ & - & 770.647 & 868.687 & 868.687 & 865.687 & 741.447 \\
\hline $\mathbf{3}$ & Financing costs & - & - & 213.418 & 213.418 & 213.418 & - \\
\hline $\mathbf{4}$ & Tax & - & 1.196 & 8.560 & 9.915 & 11.379 & 8.904 \\
\hline IIII. & Net Income & 0 & 200.157 & 6.335 & 4.980 & 3.216 & 321.734 \\
\hline
\end{tabular}

\begin{tabular}{|l|l|c|c|c|c|c|c|}
\hline Projekti B & \multicolumn{6}{|c|}{ Cash Flow } \\
\hline \multirow{2}{*}{ No. } & \multirow{2}{*}{ Description } & \multicolumn{5}{|c|}{ Years } \\
\cline { 2 - 8 } & & 0 & 1 & 2 & 3 & 4 & 5 \\
\hline I. & Receivables & 785.700 & 923.400 & 1.042 .150 & 1.042 .150 & 1.039 .000 & 1.031 .485 \\
\hline $\mathbf{1 .}$ & Revenue from sale & - & 923.400 & 1.042 .150 & 1.042 .150 & 1.039 .000 & 771.400 \\
\hline & Own financial resources & 565.700 & - & - & - & - & - \\
\hline & Loans & 220.000 & - & - & - & - & - \\
\hline & Residual value & - & - & - & - & - & 260.085 \\
\hline II. & Payments & 785.700 & 756.360 & 944.970 & 946.284 & 944.774 & 735.236 \\
\hline $\mathbf{1}$ & Investments & 785.700 & - & - & - & - & - \\
\hline $\mathbf{2}$ & $\begin{array}{l}\text { Expenditures (excluding } \\
\text { depreciation) }\end{array}$ & - & 755.200 & 851.300 & 851.300 & 848.370 & 726.600 \\
\hline $\mathbf{3}$ & Financing costs & - & - & 85.367 & 85.367 & 85.367 & - \\
\hline $\mathbf{4}$ & Tax & - & 1.160 & 8.303 & 9.617 & 11.037 & 8.636 \\
\hline $\mathbf{I I I}$. & Net Income & 0 & 167.040 & 97.180 & 95.866 & 94.226 & 296.249 \\
\hline
\end{tabular}




$$
\begin{gathered}
\mathrm{NPV}=\sum_{\mathrm{t}=0}^{\mathrm{n}} \frac{\mathrm{AN} \mathrm{t}}{(1+\mathrm{i})^{\mathrm{n}}}=0+\frac{167.040}{(1+0.08)^{1}}+\frac{97.180}{(1+0.08)^{2}}+\frac{95.866}{(1+0.08)^{3}}+\frac{94.226}{(1+0.08)^{4}} \quad+\frac{296.249}{(1+0.08)^{5}}= \\
\mathrm{NPV}=154.667+83.316+76.102+69.259+201.622=\mathbf{5 8 4 . 9 6 6 €}
\end{gathered}
$$

\begin{tabular}{|l|l|c|c|c|c|c|c|}
\hline Project A & \multicolumn{6}{|c|}{ Economical Flow } \\
\hline \multirow{2}{*}{ No. } & Description & \multicolumn{5}{|c|}{ Years } \\
\cline { 2 - 8 } & & 0 & 1 & 2 & 3 & 4 & 5 \\
\hline $\mathbf{I .}$ & Receivables & 0 & 972.000 & 1.097 .000 & 1.097 .000 & 1.093 .700 & 1.072 .085 \\
\hline $\mathbf{1}$ & Revenue from sale & - & 972.000 & 1.097 .000 & 1.097 .000 & 1.093 .700 & 812.000 \\
\hline $\mathbf{2}$ & Residual value & - & - & - & - & - & 260.085 \\
\hline $\mathbf{I I}$. & Payments & 785.700 & 771.843 & 877.247 & 878.602 & 877.066 & 750.351 \\
\hline $\mathbf{1}$ & Investments & 785.700 & - & - & - & - & - \\
\hline $\mathbf{2}$ & $\begin{array}{l}\text { Expenditures (excluding } \\
\text { depreciation) }\end{array}$ & - & 770.647 & 868.687 & 868.687 & 865.687 & 741.447 \\
\hline $\mathbf{3}$ & Tax & - & 1.196 & 8.560 & 9.915 & 11.379 & 8.904 \\
\hline $\mathbf{I I I}$. & Net Income & - & 200.157 & 219.753 & 218.398 & 216.634 & 321.734 \\
\hline
\end{tabular}

Below the Net Present Value will be calculated according to the economical flow for the project $\mathrm{A}$ and project $\mathrm{B}$ :

$$
\begin{gathered}
\mathrm{NPV}=\sum_{\mathrm{t}=0}^{\mathrm{n}} \frac{\mathrm{AN}_{\mathrm{t}}}{(1+\mathrm{i})^{\mathrm{n}}}=\frac{-785.700}{(1+0.08)^{0}}+\frac{200.157}{(1+0.08)^{1}}+\frac{219.753}{(1+0.08)^{2}}+\frac{218.398}{(1+0.08)^{3}}+\frac{216.634}{(1+0.08)^{4}}+\frac{321.734}{(1+0.08)^{5}}= \\
\mathrm{NPV}=-785.700+185.330+188.403+173.371+159.232+218.967=\mathbf{1 3 9 . 6 0 3} €
\end{gathered}
$$

\begin{tabular}{|l|l|c|c|c|c|c|c|}
\hline Project B & \multicolumn{6}{|c|}{ Economical Flow } \\
\hline \multirow{2}{*}{ No. } & Description & \multicolumn{5}{|c|}{ Years } \\
\cline { 2 - 8 } & & 0 & 1 & 2 & 3 & 4 & 5 \\
\hline $\mathbf{I .}$ & Receivables & 0 & 923.400 & 1.042 .150 & 1.042 .150 & 1.039 .000 & 1.031 .485 \\
\hline $\mathbf{1}$ & Revenue from sale & - & 923.400 & 1.042 .150 & 1.042 .150 & 1.039 .000 & 771.400 \\
\hline $\mathbf{2}$ & Residual value & - & - & - & - & - & 260.085 \\
\hline II. & Payments & 785.700 & 756.360 & 859.603 & 860.917 & 859.407 & 735.236 \\
\hline $\mathbf{1}$ & Investments & 785.700 & - & - & - & - & - \\
\hline $\mathbf{2}$ & $\begin{array}{l}\text { Expenditures (excluding } \\
\text { depreciation) }\end{array}$ & - & 755.200 & 851.300 & 851.300 & 848.370 & 726.600 \\
\hline $\mathbf{3}$ & Tax & - & 1.160 & 8.303 & 9.617 & 11.037 & 8.636 \\
\hline $\mathbf{I I I}$. & Net Income & - & 167.040 & 182.547 & 181.233 & 179.593 & 296.249 \\
\hline
\end{tabular}

$$
\begin{gathered}
\mathrm{NPV}=\sum_{\mathrm{t}=0}^{\mathrm{n}} \frac{\mathrm{AN} \mathrm{t}_{\mathrm{t}}}{(1+\mathrm{i})^{\mathrm{n}}}=\frac{-785.700}{(1+0.08)^{0}}+\frac{167.040}{(1+0.08)^{1}}+\frac{182.547}{(1+0.08)^{2}}(1+0.08)^{3} \quad(1+0.08)^{4} \quad(1+0.08)^{5} \\
\mathrm{NPV}= \\
=-785.700+154.667+156.504+143.869+132.006+201.622=\mathbf{2 . 9 6 8 €}
\end{gathered}
$$




\section{The Rank and Selection of Investing Project for Realization}

On the chart below are displayed the present net values for the project $A$ and investing project $\mathrm{B}$ calculated according to the cash flow and economical flow:

\begin{tabular}{|c|c|c|}
\hline Projects & Net Present Value by Cash Flow & Net Present Value by Economical Flow \\
\hline A & $416.044 €$ & $139.603 €$ \\
\hline B & $584.966 €$ & $2.968 €$ \\
\hline
\end{tabular}

From the data of the chart, clearly can be seen that, Project B has the net present value calculated according to the higher cash flow than the investing project $\mathrm{A}$, so in this case the investing project $\mathrm{B}$ would go into realization. However, from the data of this chart, even the investing project $A$ has the net present value calculated according to the economical flow, higher than the investing project $\mathrm{B}$, so, in this case, the investing project A would go into realization.

\section{Conclusions and Recommendations}

The causes of difference of net present value calculated according to the cash flow form that of calculated according to the economical flow is because the cash flow takes into consideration the financing sources of investing project and the financing costs. Since on the projects $A$ and $B$ the structure of financing sources changes, then financing costs change as well, whereas those affect on the amount of the net present value of these projects. Since the economical flow does not take into consideration the financing sources and financing costs, meaning that projects are equally evaluated, then I consider that the net present value which results from economical flow is more appropriate to take the investing decision.

If the investing decision is taken regarding the net present value, evaluated regarding the cash flow, a wrong decision could be taken, in order that the lower profitability project to be accepted for implementation and the project with higher profitability to be eliminated. The investing decision taken regarding the net present value, calculated regarding the economical flow will be more appropriate because it expresses the profitability of investing projects on equal evaluated conditions.

\section{References}

Gazmend Luboteni, (2015), Financat e Korporatave, FE, Prishtinë.

Koller,T., Goedhart,D.W., (2005); Valuation - measuring and managing the Value of Company, John Wiley \&Sons INC., New Jersey

Adnan Rovcanin (2010), Upravljanje Finansijama, Ekonomski Fakultet Universiteta u Sarajevu.

Halit Xhafa, (2010), Drejtimi Financiar, KUMI, Tiranë.

Pratt, P.S., (1989); Valuting a Business, the Analaysis and Appraisial of Closely Tied Companyes, Dow Jones - Irwin Homewood, Ilinois

Isa Mustafa, (2008), Menaxhmenti Financiar, RIINVEST, Prishtinë.

Pettit, J., (2007); Strategic Corporate Finance - Applications in Valuation and Capital Structure, John Wiley\& Sons, Inc., Hoboken

Ross, Westerfield, Jordan, ( 2003), "Fundamentals of Corporate Finance”, McGraw-Hill, Boston.

Mun, J., (2002); Real Options Analysis - Tools and Techniques for Valuing Strategic Investments and Decisions, John Wiley\& Sons, Inc, New Jersey

Breley, Richard, Myers, Markus, (2004), "Fundamentals of Corporate Finance", McGraw-Hill, Boston 